\title{
The current balance of power in North American hotel management contracts
}

Received: 29 February 2004

\section{Paul Beals}

is a professor at the University of Denver's School of Hotel, Restaurant and Tourism Management, where he is responsible for the MBA in hotel finance and investments. For more than 20 years his academic research and consulting have been concentrated on hotel industry development and financing, asset management and management contracts. His writings, primarily in the area of hotel finance and investments, have appeared in academic journals and other publications.

\section{Greg Denton}

is Senior Vice President of Finance and Asset Management for the Gencom Group, with responsibilities for asset management, financial and acquisition analysis for various hospitality-related investments of the Gencom Group and its affiliates. Gencom is a private developer and owner of hotels and luxury resorts throughout the USA, Canada and Mexico. He earned his bachelor's and master's degrees from the Cornell University School of Hotel Administration, has lectured frequently and has published several articles on hotel real estate finance and asset management. He currently serves as a member of the board of directors of the Hospitality Asset Managers Association (HAMA).

\section{Abstract}

This paper discusses the current status of relations between branded hotel operators and owners of lodging assets.

Although increasingly sophisticated hotel owners have gained greater input into the process of creating value for their hotel assets, there remains a fundamental misalignment of interest between operators driven to increase the number of rooms comprising the brand and the owner's objective of maximising returns from individual assets. This tension is explored by contrasting the views of the branded operator and the owner towards six management contract provisions critical to the operating flexibility and economic value of hotels: contract duration, fees and fee structures, operator financial contributions, performance clauses, termination provisions and budgetary and spending limitations. As the discussion of each provision suggests, the evolution of North American hotel management contracts over the last 30 plus years has yielded a degree of standardisation in how the provisions are structured, reducing some of the frustration felt by both parties to the agreement. The current balance of power, however, represents détente rather than a resolution of the underlying misalignment.

Tourism Management

University of Denver

2030 E. Evans Avenue

Denver, CO 80208, USA

Tel: +1 3038714271

Fax: +1 3038714260

E-mail: pbeals@du.edu

\section{Keywords:}

base management fee, branded operator, encumbered asset, fiduciary responsibility, incentive fee, owner 

Operators' controlled
negotiations

\section{Owners' increasing sophistication}

\section{INTRODUCTION}

Since the advent of hotel management contracts in North America in the 1970s, contract negotiations and the owner-operator relationship have been dictated by a volatile combination of economics and power. In some respects, the relationship can be likened to a mixture of nitroglycerin - benign, with many useful applications under normal conditions, but capable of exploding if disturbed by outside forces.

In the early years of hotel management contract negotiations, operators wielded considerable control over the process, owing to the combination of higher levels of expertise in operations and contract negotiation, and control over the brand affiliation. Thus branded operators more or less dictated contract terms to owners - who usually had little hospitality industry knowledge or experience - yielding management agreements heavily favourable to the operator. The occasional pension fund or large institutional investor was able to stand its ground in management contract negotiations due to the size of its portfolio, but in general the negotiating power rested with the operator. In such an environment, the owner's level of oversight and approval once the contract was in force is best described as blind faith.

During times of economic growth and prosperity, relations between hotel owners and operators were relatively peaceful. Owners reaped the economic benefits of hotel ownership, which outpaced returns from most other real estate investment vehicles, while operators were able to increase the number of rooms managed and their brand distribution networks without significant capital investment. Both parties benefited from the relationship, and little attention was paid to evaluating whether or not the rewards were proportional to the financial risk assumed. Since properties were performing satisfactorily, contract termination provisions were rarely invoked.

Over the past few years, the hotel owner's mentality has evolved. Owners now give serious consideration to the impact that management contract provisions have on the value of their investments, their ability to realise that value through a sale and the balance of risks and rewards available to the owner and the operator. In addition, owners now realise that the operator's interests are not always aligned with theirs, and that a degree of control over the hotel management function is necessary to protect their investment value and their flexibility.

In part, this evolution can be attributed to the economic downturns that have tested the relationship between owners and operators, revealing imbalances that owners did not previously comprehend. But the most important factor driving the shift in owners' thinking is simply the higher level of sophistication and experience found in today's hotel owners. Contemporary hotel owners are significantly more knowledgable about the hospitality industry than their counterparts in the 1970s and 1980s. Moreover, 


\section{Operator's fiduciary responsibility clarified}

\section{Better balance of power}

today's owners often employ, either internally or externally, dedicated hotel investment specialists, asset managers and legal counsel to represent their interests. Today's hotel owners have seen the impact that a long-term, 'no-cut' management contract can have on the value of their property in the event of sale; have witnessed or experienced directly the negative effects on a property of brand impact; and have read court decisions such as Woolley $v$. Embassy Suites, ${ }^{1} 2660$ Woodley Road v. ITT Sheraton ${ }^{2}$ and others that affirm owners' rights and the operator's fiduciary responsibilities to ownership.

\section{ON BALANCE, WHERE IS THE INDUSTRY?}

Many industry observers would agree that the most tumultuous period for hotel management contracts is past, and that the current environment represents a closer approximation of balance between the negotiating power of the owner and the operator. One no longer has an environment in which operators receive fees dramatically out of proportion to their levels of risk or value added, managing properties with little regard for the owner's return requirements while basking in the glow of a 50-year, nonterminable contract. In cases where operators do engage in these tactics (typically in older contracts), owners at least have legal precedents and resources they can turn to as a means of protecting their interests. Finally, although operators represent themselves as partners, owners have learned that the commercial maxim of caveat emptor applies to the selection of a property manager as much as it does to any business transaction.

If there is a more sustainable balance of power between owners and operators, it is because of the increased sophistication of owners and because of the heightened competition among hotel operating companies, including especially the larger branded hotel management companies. As hotel ownership has been consolidated in the hands of larger, more sophisticated owners, management companies have found ready customers for their services, and several have grown as publicly traded entities, reaching imposing mass but with none controlling the market. It is not unusual therefore for lodging ownership entities of even modest size to work with multiple brands and operators, each in its own way meeting the owner's needs, depending on the investment objectives, market positioning and operating requirements of a particular asset.

In the following sections of this paper the authors will attempt to describe the current balance of power between North American hotel operators and owners. This will be accomplished by analysing the operators' and owners' outlook on six critical provisions of management contracts:

- contract duration

- fees and fee structures

- operator financial contributions 
Longer terms favour operators

Strong brands can benefit owners
- performance clauses

- termination provisions

- budgetary and spending limitations.

The emphasis in the present paper is on the status of relations between owners and branded operators. Observations on management contracts in force, for example, between owners and unbranded operators, and prevailing provisions other than the six identified above are beyond the scope of the present paper and will be offered only anecdotally.

\section{CONTRACT DURATION}

The issue of management contract duration or term can be simplistically summed up by observing that the operator wants a long-term contract while the owner will always favour a shorter term. The respective rationales for these apparently irreconcilable stances deserve exploration, however, to appreciate the compromises reached in the contracts that result (or do not result).

\section{The management company's view: What is in a brand?}

Above all, branded operating companies recognise that short-term contracts are incompatible with their fundamental mission of building an enduring brand - one that enjoys a steady, predictable stream of fees, thus enabling it to evolve and adapt to maintain its franchise with the consumer. Moreover, as publicly traded, feedriven companies, the valuations of most of the largest brands depend on the duration of their management and franchise contracts. If there is a drift towards shorter terms, these annuities will inevitably decline in value, reducing a brand's share price. (It is interesting to note, however, that, among the largest brands, not all companies take advantage of the financial strength represented by the duration of their contracts, while others trumpet them to analysts and shareholders.)

Contracts of longer duration give branded operators greater bargaining power with owners, both at the negotiation stage and when modifying or implementing new brand standards. Since owners are purchasing not only operating expertise but an identity, the existence of a stable system likely to endure in the consumer marketplace is a reassurance to the owner contemplating a 20-year contract with a branded management company. In short, the owner has difficulty arguing that requirements imposed on other owners which are salutary to his interests should not also apply to new contracts. Similarly, the existence of long-term contracts reassures the owner that the management company is more likely to attract and retain competent managers, providing a depth of talent that might not otherwise be available to the individual owner. Finally, the existence of a long-term contract provides the operator with increased leverage when imposing new brand standards. Financially (and emotionally) it is easier for an owner to accept a controversial 


\section{Branding creates value}

\section{Owners seek flexibility}

brand standard if the costs are amortised over multiple remaining years of an existing contract. Even if the owner contemplates selling in the short term, the new brand standard is more readily justified if there are multiple years left to run on the contract. At best the owner can only defer the cost of meeting the brand standard, since a new owner stepping into the management contract would discount the purchase price to reflect the cost of bringing the hotel up to standard.

For many assets, the branded operator's strongest argument is that the longer the management contract, the greater the value added. Surely for a significant portion of the undistinguished boxes, large and small, found in roadside and suburban locations across the USA, this is a valid argument. Many of these hotels rely on their brand identity for their value. It is impossible to imagine their having greater value under another flag - and often the choice of the brand was dictated by the absence of that brand in the local market rather than a perfect fit between the brand and the property's physical plant or the segments served. When the power of the brand is such an important determinant of a property's success, a long-term contract with multiple years left to run can significantly enhance the value of the asset.

\section{The owner's view: Value added or encumbered?}

The length of the management contract and corresponding termination provisions are two of the most critical issues for owners in the contract negotiation phase. Owners recognise that the brand affiliation can add significant value to their property, and are not opposed to granting the operator a valuable management contract. They are, however, reluctant to encumber their asset with a franchise or management contract that might hamper their ability to make needed changes in management or sell their hotel.

Owners view the selection of an operator for their property as a contract that may, for a variety of reasons, ultimately need to be terminated. Perhaps the management company will not prove to be the most appropriate for the property; or perhaps another management company more desirable to the owner will surface. Alternatively, the ownership entity itself may decide to enter the property management business, or it may want to reserve the option to combine the property with other hotels in a larger venture involving other operators. In some instances management companies have simply proven to be ineffective operators, generating high revenue levels accompanied by bloated expenses, thus rendering the property unprofitable for the ownership. Even if no reasons for termination are immediately apparent, astute owners will simply want to retain as much flexibility as possible, leaving them free to explore options that arise in the future.

Numerous examples abound of hotels that have been marketed for sale under non-terminable management contracts or right-offirst-refusal provisions favouring the operator. The all-too-common 


\section{Branding impacts value}

\section{Conflicts of interest}

result of these provisions is that a number of prospective buyers elect not to pursue the property, either because they do not favour the operator in place or because they are aligned with a competing branded manager. By limiting the pool of prospective buyers interested in the property, these provisions curtail the bidding process and result in the owner receiving a reduced sales price. Since owners often make a sizeable proportion of their total returns from trading the asset, if owners are unable to execute a successful sale of the property this can have a devastating impact on the productivity of the investment.

Committing to a management company for a $20-$, 30- or 50 -year term can have catastrophic consequences if changes in the property, the market or the management company during that time dictate another course of action. A property or location that is suitable for a specific brand today may evolve over the life of the investment, becoming more appropriate to a different brand or tier of the lodging market in the future. Moreover, particularly in this environment of consolidation and mergers, the company the owner contracts with today may not be the same company in the future, but may instead have vastly different capital, operating or management structures. As an example, Sheraton and Westin Hotels have each gone through at least four different ownership structures over the past 20 years, operating as independent hotel companies, divisions of large conglomerates and divisions of Starwood Hotels in its incarnations as a paired-share REIT (real estate investment trust) and today's C-corporation. Owners who contracted with the Sheraton and Westin brands in the 1970s may still be bound by their original contracts, but they probably did not bargain for their operators becoming the quite different entities they are today. Under such circumstances, owners need the flexibility to change or terminate the management contract.

Moreover, owners take exception to the operator's stance that its fundamental mission is to build an enduring brand, arguing that they are paying the branded operator significant sums of money to manage their specific hotels. The owner would clearly prefer the operator to have brand value if that value translates into higher performance for the owner's property. But if the brand value comes at the owner's expense, or if the operator engages in activities that detract from the profitability or marketability of the owner's specific hotel for the good of the brand, the brand's value added is more than offset by the decline in the value of the owner's property. Effectively, the owner is subsidising the brand's stock price.

The hospitality industry as a whole is becoming increasingly attentive to the inherent conflicts of interest between the operator's fiduciary responsibility to the individual owner and the operator's fiduciary responsibility to its shareholders. Decisions that an operator makes may be in the best interests of the firm's shareholders but may be detrimental to specific owners or groups of 


\section{New balance of power}

\section{Operators exercise patience}

owners, thus putting the operator in the difficult position of having to decide which of two masters to serve. A number of lawsuits have been waged against operators who do not act in the best interests of their owners, lending greater credence to owners' concerns about where operators' loyalties lie and the fairness of management contracts binding them to operators for long terms.

\section{FEES AND FEE STRUCTURES}

As suggested above, the balance of power has shifted, providing a more equitable sharing of risks and rewards between operators and owners. Perhaps the most surprising aspect of the shift in the balance of power is that it has occurred not because one party has gained ascendancy over the other, as was the case in the 1970s and into the 1980s when management companies dictated terms to owners. Rather, the new balance of power results from the increasing strength of both parties. This is nowhere more evident than in the fees and fee structures currently practised in North American management contracts between branded operators and owners.

\section{The management company's view: Fair compensation for value added}

Executives at branded management companies concede readily that earlier fee structures and operator compensation were inequitable and excessive. But the same executives argue forcefully that if the operator reduces the owner's business risk and builds asset value, then fair compensation is due to the operator. Similarly, they argue that owners must appreciate the need for the brand to evolve to meet guest preferences, expand system-wide services and provide new technologies. These incremental expenditures benefit participants in the system; the costs must therefore be passed along to owners and cannot be absorbed by the operator, especially if the operator is a publicly traded entity that must meet growth and earnings objectives to protect shareholder value.

Notwithstanding this stance, operators are willing to exercise patience, accepting lesser fees in the early years of the management contract's term. In some instances, the operator's patience is motivated by a desire to do 'strategic' deals - ie accept contracts whose fees are inferior to the norm in exchange for gaining market penetration, or 'distribution', for the brand. In virtually all cases, the competitive landscape demands that the operator subordinate incentive fees to an owner's return, although the level of appropriate preferential return to the owner varies significantly according to the specifics of the deal and concessions the owner and operator might win in the negotiation of the management contract.

\section{The owner's view: Sharing risks and transparency}

Most owners agree with the basic concept of compensating operators for the value that they bring to a project. But from the 
Base versus incentive fees

\section{Services billed separately}

owner's perspective, the balance between just compensation versus the sharing of risks is best achieved by structuring appropriate levels of base and incentive management fees in the management contract. Historically, owners considered the base management fee to be the operator's vehicle for recovering corporate overhead expenses and ensuring a minimal level of profitability. In contrast, the incentive management fee has been the means for the operator to share in the hotel's profitability, thus receiving compensation for the value the operator provides through its management and brand. This balance mitigates the operator's risk by ensuring receipt of a fee stream that is not contingent on the hotel's profitability, but also rewards the operator for superior performance by giving up a portion of the property's profits via the incentive fee. Additionally, motivating the operator to earn incentive fees gave owners comfort that the operator was driving profits at the property instead of focusing solely on revenues. From the owner's vantage point, the operator should realise a modest profit from the base management fee in exchange for reducing the owner's financial risk, but the operator should enjoy the opportunity to realise substantial profits only if the property achieves a reasonable level of profitability.

But the roles of these fees, particularly the base management fee, have blurred over recent years, thus shifting the debate from 'what is fair compensation to the operator?' to 'what are we getting in exchange for the base management fees?'. Currently, the most contentious issues between owners and operators involve the recovery of shared costs and overhead expense pass-throughs that owners formerly considered included in the base management fee but which are now invoiced in addition to the base management fee.

Examples of operator services and costs that are now billed to hotels separately in addition to the base management fees include the following.

- centralised marketing services

- group sales offices

- frequent-guest programmes

- purchasing programmes

- accounting fees

- software licensing and support fees

- network/management information services licensing and support fees

- employee training/satisfaction programmes

- guest satisfaction programmes

- brand compliance inspections

— internal audits.

In the aggregate, these corporate expenses and fees can represent as much as 3-5 per cent of total revenues in addition to the base management fee paid to the operator, thus converting the base 


\section{Base fee contains significant profit}

\section{Operator financial contributions: Changed outlook}

management fee from a modestly profitable item to one of substantial profitability for the operator, since a large proportion of the operator's expenses are reimbursed from the properties. In addition to the sheer magnitude of these expenses, owners are often dissatisfied with the specific items that are included within the reimbursements, such as the recuperation of corporate research and development expenses and personnel costs that were formerly covered by the base management fee. Owners' concerns have been heightened by inadequate disclosure and the lack of transparency in operators' financial reporting, which has failed in a number of cases to account properly for expenses charged to properties in the system.

As stated above, the net result of these increased cost allocations to the properties is that the base management fee is now perceived by owners as constituting a significant profit component instead of being largely a vehicle for recovering corporate overhead expenses and a modest profit component. Indeed, operators estimate that 1 per cent of the average 3 per cent base management fee represents profit to the management company, although one of the largest companies places the estimate at 2 per cent, which owners view as shifting more expense (and risk) on to their shoulders. This is often cited as justification by owners when asking for reduced term lengths and more meaningful performance provisions, because the operator is no longer perceived as a partner sharing in the risks of the venture but as an agent of ownership who profits regardless of whether or not the hotel is successful.

\section{OPERATOR FINANCIAL CONTRIBUTIONS}

Although publicly traded hybrid lodging companies that are owners, operators and franchisors continue to exist, none currently plans to grow systematically by increasing ownership of assets. In fact, the recent decision by several publicly traded North American lodging companies - eg Marriott, Hilton Hotels, Starwood - to shed owned properties confirms this tendency toward an emphasis on fee-based income over ownership returns. Hybrid companies may occasionally grow opportunistically by acquiring key strategic assets or joint venturing with private ownership entities, but the emphasis will continue to be on growing earnings streams by adding managed and franchised rooms. Not surprisingly, in the current environment, the outlook on operator equity investments in lodging projects has changed considerably from the earlier days of management contracts, when owners demanded that operators put significant dollars at risk - a mentality summed up by the observation of one owner: 'If I have the hurts, I want him [the operator] to have the hurts, too.'

\section{The management company's view: Lean earnings machines}

Most branded management companies identify themselves resolutely as publicly traded service firms that eschew, where 


\section{Publicly traded operators eschew investment}

\section{Private operators frequently invest}

possible, the ownership of real estate. For companies practising this strategy, an investment in a hotel project is a threat to the earnings stream that underpins their value on Wall Street. Under increasingly stringent post-Enron accounting rules, even modest minority interests may be required to be reported under the equity method, resulting in the consolidation of accounting losses with the operator's earnings and a decline in the company's balance-sheet value as a result of the minority interest.

Debt investments and credit enhancement also represent disadvantages to publicly traded operators. Loan guarantees that operators might offer to secure management contracts must be disclosed as contingent liabilities, and analysts routinely include these contingent liabilities as part of operators' debt, adjusting their risk assessment accordingly. Similarly, loans made to secure management contracts must earn at least market returns or analysts adjust downward the value of the fee stream purchased by extending subsidised credit.

Finally, branded management companies incur an opportunity cost when a given management contract is accepted, especially if the contract is for the operation of a property in a particularly desirable market. Development officers at branded management companies acknowledge that one of their functions is to act as gatekeepers, ensuring that only the most promising opportunities and partners gain access to the brand's expertise. In this environment, executives at branded management companies are chary of making financial contributions in any form to some deals, reasoning that, by passing on other projects to accept the opportunity and subordinating their incentive fees, they have shouldered adequate risk.

Independent, unbranded management companies have a similar outlook on investing in hotel projects, but are typically less constrained by balance-sheet issues (unless they too are publicly traded). The intensely competitive environment for all management companies, whether branded or unbranded, as well as the strong financial returns available from investments in lodging assets are an incentive for independent management companies to provide capital to projects. When coupled with their management fee stream, independent management companies' cash-on-cash returns can reach 20-25 per cent, and it is not surprising therefore that an increasing number have allocated investment capital for the purposes of making 'sliver' equity investments or other forms of financial contribution to win management contracts and grow their inventories of managed rooms.

\section{The owner's view: Expensive capital or grease that gets the deal done?}

The owner's view of management company investments varies dramatically, depending on the project economics, the capital resources and investment philosophy of the individual owner and 


\section{Dangers of operator contributions}

Key money the salient terms of the management contract - eg length of term, termination provisions, etc - that impact on the owner's risk exposure and the potential value of the property.

Owners seeking aggressive investment returns or those willing to accept higher risk profiles often view operator contributions as a critical source of capital and a means of reducing their financial commitment to a project. They evaluate operator capital contributions, both financially and in terms of other contract concessions, comparing their cost to the cost of mezzanine debt or other high-yield components of the project's financial structure. This type of owner will pursue operator contributions so long as the capital is 'accretive' - ie the cost of the operator's money is lower than the projected yields on the investment.

More conservative owners often have a different outlook on operator contributions, viewing them as an unnecessary complication in the deal structure and capital that is expensive in more than a strictly financial sense. By taking a minority equity position in hotel properties, operators have claimed the legal status of an 'agency coupled with an interest', using the status to avoid termination of the management contract on the basis that their equity position makes them a partner and protects them from termination under any circumstances. These arguments have met with varying success in the courts. But even if the arguments are not ultimately sustained in court, accepting equity contributions from the operator, and thus opening the door to this potential issue, is undesirable to many owners. These owners prefer to maintain more of an arm's-length relationship with their operators, and recognise that they may be able to negotiate other concessions from the operator that are of more importance to them if they do not require an equity investment in the property.

The one arrangement whereby both aggressive and conservative owners appear to accept contributions from operators is in the form of 'key money' - outright contributions to the project that are typically only repaid if the management contract is terminated prematurely. Operators' willingness to provide key money contributions can be considered a tacit admission of the profitability of today's management contracts (as discussed above). It is often viewed by owners as the owner's version of an incentive management fee - ie a means for the owner to share in the profits of the operator.

\section{PERFORMANCE CLAUSES}

Over recent years, performance clauses have become a regular feature of hotel management contracts. Executives at branded management companies could not recall a recent management contract that did not contain a performance clause, and all agreed that they will be a fixture of future management contracts. Despite the apparent agreement between owners and operators that the inclusion of performance clauses in management contracts is 


\section{Structuring performance clauses}

prudent and necessary, structuring an effective performance clause is not an easy exercise. On the one hand performance clauses must provide a reasonable flexibility to the operator in the face of unforeseen market conditions and other exigencies, while on the other hand they must represent meaningful performance standards that owners can invoke to protect their interests.

\section{The management company's view: Flexibility and reasonable tests}

Executives at branded operators express the view that if the management company is not performing adequately, the owner should have the right to terminate the contract. Furthermore, they appreciate that if the operator has relatively little cash at risk in a project, it is reasonable for the owner to seek an effective means of ensuring that the property is managed to achieve optimal results for the owner.

But while operators accept that they should be held to performance standards, they maintain they should be protected from market vicissitudes outside their control and that standards must be set to allow some shortfall. In a similar vein, they hold that there must be a reasonable period after the management company takes control of an asset before the performance standard can be invoked and the contract potentially terminated. Finally, while they want the option to contribute cash to cure shortfalls in performance standards, they acknowledge that, if the property consistently underperforms, going out of pocket repeatedly does not adequately address the owner's concerns.

\section{The owner's view: Last line of defence to remedy a bad situation}

It is rare to find a hotel owner who disagrees with the logic stated above - that performance standards should be reasonable and operators should have the opportunity, within defined limits, to cure shortfalls to avoid termination. The primary difference between owners and operators lies with the definitions of what is a reasonable standard and what counts as a market factor or force majeure event that would preclude termination.

It is important to point out that the increased use of performance standards is viewed as largely a result of operators' insistence on long-term contracts. Furthermore, the perception that operators no longer share in the risk of the property because they recoup a substantial portion of their overhead costs through add-on fees while pocketing much of a base management fee as profit contributes to ownership's need for an 'out' if the property is not achieving acceptable returns. The combination of these two factors means that, in the absence of performance standards, an operator may have a highly profitable, long-term income stream from the base management fees, service fees and expense pass-throughs while the hotel itself is losing money. In the absence of a mechanism for 
Top- and bottomline tests remedying this situation, owners could be driven slowly (or rapidly) into bankruptcy while the operator lives well because of the topline-oriented fee structure.

Performance clauses most often proposed by operators are RevPAR (revenue per available room) tests whereby the owner may terminate the manager if the property fails to achieve a predetermined percentage of its competitive set's RevPAR levels. These strictly top-line-oriented tests are not particularly meaningful to owners because they do not measure the property's profitability. An operator can achieve strong RevPAR levels by providing extremely high levels of services and amenities, but if doing so hampers the property's profitability, then meeting the RevPAR test should not save the operator from termination.

The reassurance that owners seek from performance standards is that minimum profitability levels will be achieved, enabling the property to meet its debt service and other obligations and remain a viable hotel investment. To ensure that ownership's objectives are met, a bottom-line performance test is a sine qua non. Focusing on profit measures leaves the day-to-day management decisions in the hands of the operator (where they belong), but commits the operator to generating a minimum level of profits based upon either the projections originally agreed to at the commencement of the investment, or a predetermined percentage return on the total investment that enables ownership to make debt service payments and provides the minimum return needed to induce equity investment in the project.

Owners see termination provisions as a fail-safe mechanism that allows them to salvage a property when the operator is failing to manage it effectively, not a weapon enabling them to terminate operators indiscriminately. Owners also point out that terminating and replacing a management company is an expensive proposition that is often disruptive to the property; therefore it is not an action undertaken lightly. Thus, even when termination provisions may allow them to replace the operator, owners are unlikely to do so unless there is good cause, or another operator is realistically expected to perform significantly better.

\section{TERMINATION PROVISIONS}

Although the authors (and their spouses) find analogies comparing management contracts to marriages unsettling on several levels, the negotiation of termination provisions in a management contract can be loosely compared to the negotiation of a prenuptial agreement. Under normal circumstances the termination provisions are not enforced, but rather they exist as a safety net for both the owner and the operator to fall back upon if, for whatever reason, the union is not working.

The increasing strength of branding militates against owners' natural inclination to seek termination clauses to ensure flexibility in managing and disposing of their assets. Assuming they have 
Maintaining the fee stream

\section{Maintaining flexibility}

negotiated a contract term of acceptable duration, owners who are convinced that a given brand is the optimal choice for maximising the value of their assets are less inclined to put a high priority on termination clauses in the negotiating process. Similarly, operators who perceive that their brand represents a superior - or the only - fit with owners' investment objectives, market positioning and operating requirements are likely to be even firmer in their resistance to termination provisions.

The pressure to increase the number of rooms in their systems appears to be leading branded operators to focus less on management contracts and more on the durability of the franchise agreement, preferring more readily achieved increases in their system distribution and the brand's royalty fee stream to the incremental fees potentially derived from managing. Independent operators, however, have no such assurances of a residual income stream in the event of management termination, and therefore tend to cling more forcefully to tempering the impact of termination provisions.

\section{The management company's view: Protecting share price}

For branded operators that are public companies heavily dependent on a long-term earnings stream to support their market valuations, preserving consistent fee revenue is of paramount importance. To the extent that termination provisions threaten future earnings and diminish current market valuations, they are an anathema. When buy-out provisions are admitted in contracts, branded publicly traded operators strive to achieve terms that make the company whole, attempting to negotiate a lump-sum buy-out payment equivalent to the present value of the fee revenue forgone.

Termination-on-sale provisions, regardless of how they are priced, are viewed as especially detrimental to the operator's interest because they invite renegotiation of the contract.

\section{The owner's view: Protecting asset value}

Owners who allow management companies to impose long-term contracts with no termination provisions run the risk of seriously impairing the value of their investments. Investing in hotels is not an activity for the fainthearted, as investors are buying into one of the most difficult real estate property types to develop and manage. Moreover, hotels are highly subject to the risk suggested by the real estate aphorism 'locations don't change, but neighbourhoods do'. If owners are to protect the value of their assets, they need some basic level of flexibility over the long term to make needed changes to the property.

For an owner cognisant of the potential impact on market value of an encumbered asset, a long-term contract with no performance clauses or other termination provisions is the worst possible management structure. An alternative that is somewhat less painful for the owner is the inclusion in the management contract of a 
Buyouts and tradeoffs

A careful balance termination-with-fee provision or buy-out clause that enables the owner to compel the manager to leave the property at the owner's discretion, but at a steep price. The negotiation of a buy-out clause at least caps the diminution in value the owner will be forced to bear. When the time comes to sell, if the property is performing well and the buyer wishes to retain the manager, the owner is not harmed financially. But if the buyer does not wish to retain the current management, the owner can quantify the downside impact.

Another area of concern for owners in the negotiation of termination provisions is the attempt by operators to incorporate language enabling them to terminate the brand affiliation for vaguely worded actions (or inactions) of the owner. Such provisions are perceived by owners as depriving them of their rights to question or approve the actions of the operator, effectively forcing them to relinquish control over their properties. For example, categorising the failure to approve the annual operating budget as an ownership default - and thus grounds for termination - removes owners' ability to question the budget unless they are willing to forfeit the management and brand affiliation. Similarly, if owners deem capital expenditures inappropriate or lacking in cost effectiveness, they need to maintain the ability to withhold the funding reasonably without triggering the operator's right to terminate the contract.

Owners are also increasingly aware of the risks imposed by a change in control of the management company; accordingly, they are seeking additional rights to terminate the management agreement when such events occur. A change-in-control clause is largely a defensive mechanism on the part of owners who are concerned that the company they have contracted with may not be the same company in the future, or may undergo changes at the upper levels of the executive team that dramatically alter the philosophies or management capabilities of the operator. Similarly, the risk of a diminution in brand distribution, particularly for small boutique hotel brands, has led some owners to seek the ability to terminate the contract if the operator does not achieve or maintain a defined portfolio size over the course of the contract.

\section{BUDGETARY AND SPENDING LIMITATIONS}

As hotel asset managers recognise daily, owner-operator relationships are necessarily collaborative and consultative. This principle is nowhere more evident than in the negotiation of a property's budgets. The relationship represents a careful balance, preserving the operator's right to maintain brand standards and operating norms while providing ownership with input into decisions requiring the disbursement of significant sums of the investor's funds.

\section{The management company's view: Strength in numbers}

The branded operator's insistence on preserving the right to mandate expenditures hinges on two fundamental arguments. First 
and foremost, the branded operator maintains that what is good for the system is good for the individual owner. Expenditures are required to protect and enhance brand integrity and pricing power. As the brand is strengthened and its consumer franchise extended, all owners' asset values increase. Secondly, the branded operator maintains that system-wide efforts are cost efficient, providing owners with services and enhancements to the guest experience that owners could not afford individually.

\section{The owner's view: Good for all?}

Owners maintain - and recent history has confirmed — that the conflicts and misalignment of interests between owners and operators preclude owners from accepting the 'trust me, I know what's right for you' stance often taken by the operator. The notion that the operator will spend the owner's money in the wisest, most prudent manner has been debunked all too often, in the field and in the courts, to be relied upon by any but the most naïve of owners.

Evidence assembled from the membership of the Hospitality Asset Managers Association (HAMA) ${ }^{3}$ shows a strong correlation between the intensity and sophistication of the asset management techniques employed in overseeing a property and the financial returns the property generates for ownership. Active oversight produces higher returns than passive ownership, and one of the basic and most critical of asset management techniques employed is to review and critique operating budgets, and to hold management accountable for expenditures that are either imprudent or poorly managed.

To their credit, the majority of management companies have acceded to owners' desires to be actively involved in the budgeting process, although owners must still insist on full approval rights and not settle for watered-down provisions allowing them only to comment on areas of concern. This change in thinking represents a watershed that was unimaginable 20 years ago, and is largely attributed to the coordinated efforts of a number of owners who insisted upon having these rights.

\section{CONCLUSION}

As with any negotiated working arrangement, the specific provisions agreed to between an owner and the operator are subject to wide variation, depending on the balance of power between the two parties and each entity's level of motivation. Large, sophisticated owners with multiple high-profile properties negotiating against smaller independent or highly motivated branded management companies will win more concessions from the operator than a small owner with one hotel in a secondary location.

But two important trends appear to have surfaced in the negotiation of hotel management contracts over recent years. First, the onerous contract length and non-termination provisions 


\section{A more equitable balance}

\section{Simplified business models}

formerly imposed by managers appear largely to have come into a more equitable balance, with operators still receiving relatively long-term contracts but with owners enjoying a basic level of rights over performance and termination. Secondly, evidence suggests that owners have become markedly more astute, knowing better what to ask for in their negotiations. The authors attribute this to a combination of increasingly sophisticated owners, and greater dissemination of information and counsel from industry commentators, consultants, asset managers and attorneys.

The reader who has followed the give and take of the preceding pages might wonder if the authors - each of whom has purposely adopted (evenhandedly, it is hoped) the mantle of the owner and the operator - are able to agree on any aspect of the preceding debate. If there is an area of agreement, it is in what the future is likely to hold for branded management companies.

Recent issues highlight the inherent conflicts of interest when a branded hotel company is an owner of hotels, a manager of others' hotels, a franchisor and a publicly traded company. The dynamics suggest that the trend towards vertical integration - which, for some entities, is an artefact of the mergers and acquisitions that occurred in the North American lodging industry in the 1990s will reverse. Branded management companies will tend towards either the management business (Hyatt, Four Seasons Hotels) or the brand business, but staying in both in a meaningful way will increasingly conflict with their status as public companies. To the extent that branded management companies do move towards a branding 'pure play', the balance of power may swing in favour of the owner, as control over the brand affiliation is one of the management company's most effective bargaining chips. The landscape will also favour non-public, entrepreneurial operators who are able to align their interests (and their dollars) more effectively with owners' interests.

\section{ACKNOWLEDGMENT}

Portions of the present paper appeared as Chapter 6 in Hotel Asset Management: Principles and Practices, published by the University of Denver and the Educational Institute of the American Hotel and Lodging Association.

\section{References}

1. Robert E. Woolley, et al.v. Embassy Suites, Inc., et al., 227 Cal. App.3d 1520 (1991).

2. 2660 Woodley Road Joint Venture, et al. v. ITT Sheraton Corporation, et al., 1998 WL 1469541 (D. Del).

3. For more information on the Hospitality Asset Managers Association (HAMA), see Beals, P. (2004) 'The history of hotel asset management', in Beals, P. and Denton, G. (eds) Hotel Asset Management: Principles and Practices, University of Denver and the Educational Institute of the American Hotel and Lodging Association, East Lansing, MI, pp. 11-12. See also: www.hamainfo.com. 